Fisheries Research

September 2016, Volume 181 Pages 116-126

http://dx.doi.org/10.1016/i.fishres.2016.04.002

http://archimer.ifremer.fr/doc/00332/44359/

(c) 2016 Elsevier B.V. All rights reserved.

\title{
A new approach to determine the distributional effects of quota management in fisheries
}

\author{
Bellanger Manuel ${ }^{1,{ }^{*}}$, Macher Claire ${ }^{1}$, Guyader Olivier ${ }^{1}$ \\ ${ }^{1}$ Ifremer, UMR AMURE, Unité d'Economie Maritime, BP 70, F-29280 Plouzane, France \\ *Corresponding author :Manuel Bellanger, email address : manuel.bellanger@ifremer.fr
}

\begin{abstract}
:
Quota allocation mechanisms have distributional effects that are highly relevant to the economic organization of fisheries. In France, where fishing allocations are non-transferable, quotas are shared among Producer Organizations (POs) based on the historical landings of their members. Each PO is then responsible for implementing their own internal rules that provide individual or collective allocations to their members. This study investigates the distributional effects of the various quota management systems adopted by POs on quotas and production for the Bay of Biscay sole fishery. A comparison between initial allocations by vessel based on historical landings and actual observed landings is presented. Inequality metrics are used to quantify distributional effects, and a new method that is based on the decomposability property of the Theil index is introduced. Results show that the French management system successfully avoided concentration of production while reducing the fishing capacity through decommissioning schemes. The non-transferability of fishing allocations is a critical element that favored this outcome by allowing POs to control the distribution of catch shares in the fishery. Besides, it appears that the allocation strategies developed by POs were notably influenced by their local roots and their fishing fleet profiles. The various quota allocation systems among POs had contrasting effects on vessels' production, including greater equity within particular subfleets, benefits to vessels most dependent on sole in most POs, and benefits to the small-scale fisheries in a few POs.
\end{abstract}

\section{Highlights}

The role of producer organizations in the French quota management system is critical. Reduction of fleet capacity was achieved without concentration of production. Non-transferability of allocations favored greater equity in the fishery. Producer organizations' allocation strategies are influenced by their local identity. The Theil index offers some unique advantages to analyze distributional changes.

Keywords : Distribution, Inequality, Producer organizations, Catch shares, Common-pool resources, Fishery management 


\section{Introduction}

In Europe, the management of fisheries mainly relies on Total Allowable Catches (TACs) set by fish stock and distributed to member states according to historical allocation keys (Holden, 1994). Each member state is then responsible for managing its own quotas, and different countries allocate their quotas among producers using various systems (Le Floc'h et al., 2015). In its Green Paper on European Union Common Fisheries Policy (CFP) reform, the European Commission (2009a) suggested that individual Transferable Fishing Concessions (TFCs) - a right-based management system similar to the well-known Individual Transferable Quotas (ITQs) - should be considered, at the European level, as a potential solution to tackle the deep-rooted problem of overcapacity seen as the main structural failing of the CFP. Some EU countries (The Netherlands, Denmark, Spain and the United Kingdom) have actually implemented ITQs systems in the past decades (González Laxe, 2006; Marchal et al., 2009; Aranda and Murillas, 2015). However, the French administration, following the position of fishermen's representatives, took position against the generalization of ITQs (Gouvernement Français 2009, p.29) in a memorandum arguing that ITQs would eventually result in fishing rights concentration and destabilization of local fishing communities. In order to maintain economic and social equilibriums in French territory, the French administration supported the current quota co-management system implemented by Producer Organizations (POs) (Larabi et al., 2013).

Quota allocations in catch share programs deal with important issues because of their biological (Branch, 2009), economic (Squires et al., 1995; Grafton, 1996; Asche et al., 2008) and social (Pálsson and Petursdottir, 1997; Soliman, 2014) implications. Issues of wealth redistribution and heterogeneity may disrupt the performance of quota management systems (Karpoff, 1987; Grainger and Costello, 2015) and distributional effects of quota allocation on production and economic returns are critical towards addressing issues of fairness and acceptability (Copes, 1986). Yet these distributional effects are rarely studied and many authors have argued that they should be given more attention (e.g., Bromley and Bishop, 1977; Copes, 1986; Copes and Charles, 2004; Matthíasson, 1992; Wilen and Casey, 1997; Guyader and Thébaud, 2001; Thébaud et al., 2012). These issues are particularly significant in the French context where large-scale and small-scale fisheries coexist (Daurès et al., 2009; Guyader et al., 2013) and equity in rights of access to fisheries resources is at stake (Le Gallic et al., 2005; see also Gray et al. 2011 for an English case study). Quota distribution also relates to environmental concerns about the usage of active (e.g., trawls) vs. passive (e.g., gillnets) fishing gear for the harvest of demersal species (Branch, 2009). Besides, the French quota management system is based on POs that have strong territorial roots and as such their strategies in terms of membership dynamics (e.g., POs are not required to accept any membership requests from fishermen) and quota distribution may also influence the rights of access to resources of local fishing communities. This study therefore addresses the questions of quantifying the distributional effects of the French quota governance system and whether the quota management by POs limits inequalities and concentration of production.

The debate that occurred in France - and in other EU countries - during the Common Fisheries Policy reform raised the question of which quota management system should be adopted (European Commission 2010). Two main options were Individual Transferable Quotas (ITQs) markets and co-management systems where allocations are granted to groups of harvesters. Extensive literature exists on their respective potential to provide solutions as sustainable fishery management systems (e.g., Jentoft, 1989; Ostrom, 1990; Copes and Charles, 2004; Grafton et al., 2006; Costello et al., 2008; Gutiérrez et al., 2011; Deacon, 2012), but little is known about their influence on wealth distribution in terms of winners / losers within a fishery. There are two main approaches used to study distributional effect in the fisheries economics literature. The first uses theoretical models to investigate outcomes of 
alternative management regimes (Dupont and Phipps, 1991; Salvanes and Squires, 1996; Armstrong and Clark, 1997; Sumaila and Armstrong, 2006). The second is the application of inequality metrics to empirical data to quantify the changes in harvest distributions, often related to a change in management such as the introduction of ITQs (Connor, 2000; Hamon et al., 2009). Our paper falls into this later type of approach and addresses the case of PO-based co-management, as implemented in some EU countries, and which has not yet been empirically addressed in a quantitative way.

Quantifying distributional effects first necessitates a clear understanding of the initial situation or initial quota allocation from which redistribution occurs. Then it requires selecting appropriate metrics. The inequality metrics that are most commonly found in the fisheries economics literature typically measure inequality in the population as a whole (Hamon et al., 2009; Adelaja et al., 1998; Gauvin et al., 1994), and not much attention is paid to the inequality within and between subgroups of vessels (Armstrong and Clark, 1997). In particular, consideration of different scales offers insight for the analysis of distributional changes to the primary and secondary contributors to the fishery, which is essential in the context where large-scale and small-scale fisheries operate alongside one another using various fishing gears. Our paper discusses the relevance of different inequality metrics for the exploration of distributional effects of quota management and introduces a new method which uses the decomposability property of the Theil index (Theil, 1967; Bourguignon, 1979) to decompose the inequality into subgroups of vessels and determine the between and within components.

The Bay of Biscay common sole (Solea solea) fishery was the first fishery where individual vessel quotas (IVQs) were used in France in 2006, and this management innovation tends to be generalized to many of the most important French fisheries (Le Floc'h et al., 2015). This paper therefore uses this influential fishery to investigate the distributional effects of the quota management systems adopted by POs on sole landings based on the 2011 reference year. Actual landings observed were compared to a simulated initial situation based on historical landings by vessel that corresponds to the current rule defined by the French administration for allocating collective sub-quotas to POs and could virtually be used as an individual initial allocation in an ITQ system. Decompositions by fishing gear used, length class and maritime district were employed to analyze the differences between the initial and the final situations.

\subsection{Structure and evolution of the Bay of Biscay sole fishery}

The demersal fisheries of the Bay of Biscay - i.e. operating in ICES divisions VIIIa-b are commonly referred to as mixed fisheries, because the catches of vessels operating in this area are usually composed of a mix of various species. The common sole fishery has a long history of being one of the main fisheries in the Bay of Biscay as sole has been the first species in value for the last several decades. These fisheries are mainly composed of French vessels that catch about $92 \%$ of the TAC, and trawl and gillnet are the main fishing gears used.

In 2011, the French Bay of Biscay sole fishery was composed of 472 vessels that landed more than one ton of sole (Table 1). The number of vessels operating in the sole fishery (Fig. 1a) has been decreasing between 2000 and 2011 (-21\%), due mainly to decommissioning schemes (Quillérou and Guyader, 2012).

Total landings of sole in 2011 were 4,259 tons (Fig. 1b) and generated gross revenue of 54 million euros. The sole gillnetters were the greatest sole producers $(22.6 \mathrm{t}$ per vessel in average) as well as the most dependent on this species (57.4\% of their gross revenue in average). Their contributions to the fishing mortality of sole were about $68 \%$. The mixed gillnetters (that catch a mix of species) constituted a smaller fleet less dependent on sole, with smaller vessels and smaller crew sizes than the sole gillnetters. The trawlers - for which the 
Table 1. Number of vessels and average vessel characteristics by fleet segment of the Bay of Biscay sole fishery in 2011 (vessels with annual landings > 1 metric ton)

\begin{tabular}{|c|c|c|c|c|c|c|c|c|}
\hline Fleet segment & $\begin{array}{c}\text { Number } \\
\text { of } \\
\text { vessels }\end{array}$ & $\begin{array}{c}\text { Vessel } \\
\text { length } \\
\text { (m) }\end{array}$ & Crewsize & $\begin{array}{c}\text { Days at } \\
\text { sea }\end{array}$ & $\begin{array}{c}\text { Gross } \\
\text { revenue } \\
(\mathrm{k} €)\end{array}$ & $\begin{array}{c}\text { Sole Gross } \\
\text { revenue } \\
\text { (k€) }\end{array}$ & $\begin{array}{c}\text { Sole } \\
\text { Landings } \\
\text { (Tons) }\end{array}$ & $\begin{array}{c}\text { Sole } \\
\text { dependency } \\
\text { (\% Gross } \\
\text { revenue) } \\
\end{array}$ \\
\hline Sole gillnetters & 138 & 13.6 & 3.7 & 197 & 469 & 269 & 22.6 & 57.4 \\
\hline Mixed gillnetters & 28 & 9.8 & 1.9 & 141 & 134 & 20 & 1.4 & 14.7 \\
\hline $\begin{array}{l}\text { Specialized } \\
\text { Nephrops trawlers }\end{array}$ & 85 & 14.4 & 3.2 & 211 & 454 & 42 & 3.6 & 9.2 \\
\hline $\begin{array}{l}\text { Non specialized } \\
\text { Nephrops trawlers }\end{array}$ & 53 & 15.6 & 3.5 & 225 & 628 & 75 & 6.9 & 11.9 \\
\hline $\begin{array}{l}\text { Inshore mixed } \\
\text { bottom trawlers }\end{array}$ & 75 & 10.6 & 1.9 & 152 & 193 & 37 & 3.2 & 19.4 \\
\hline $\begin{array}{l}\text { Offshore mixed } \\
\text { bottom trawlers }\end{array}$ & 30 & 17.5 & 3.8 & 227 & 682 & 59 & 5.5 & 8.6 \\
\hline Others & 63 & 12.2 & 2.7 & 196 & 353 & 37 & 3.0 & 10.6 \\
\hline Average & - & 13.3 & 3.1 & 194 & 419 & 110 & 9.4 & 25.7 \\
\hline
\end{tabular}

sole could either be a target species or a bycatch - accounted for more than half of the vessels participating in the fishery. The Nephrops trawlers can be differentiated by their degree of specialization - i.e. the share of their gross revenue depending on nephrops (Nephrops norvegicus) - which also corresponds to diverse fishing strategies along the course of the year (Macher et al., 2011; Raveau et al., 2012). Although their dependence on sole was quite low, their contribution to sole fishing mortality was significant (respectively $8 \%$ for the nonspecialized nephrops trawlers and $7 \%$ for the specialized nephrops trawlers). The mixed bottom trawlers catch a mix of species, including hake (Merluccius merluccius), nephrops and sole. The inshore mixed bottom trawlers had an average dependency to sole of $19.4 \%$ and average sole landings of $3.2 \mathrm{t}$ whereas offshore mixed bottom trawler were less dependent on sole $(8.6 \%)$ and had greater landings $(5.5 \mathrm{t})$.

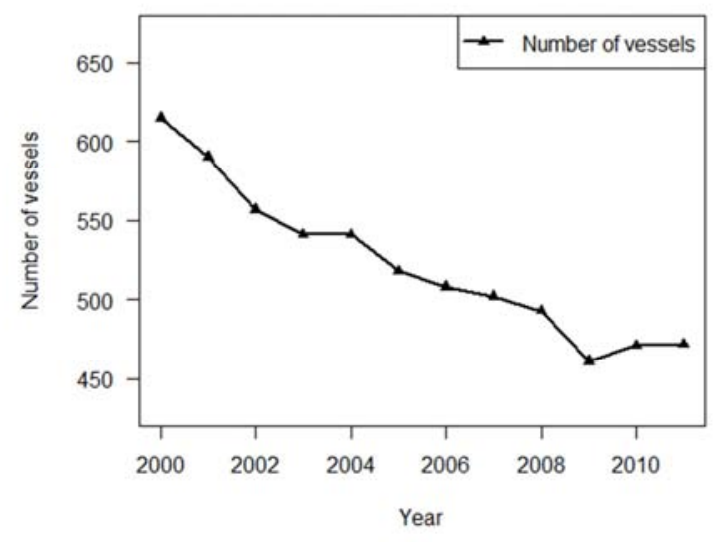

Figure 1a. Evolution of the number of vessels participating in the Bay of Biscay common sole fishery (vessels with annual landings $>1 T$ ) between 2000 and 2011.

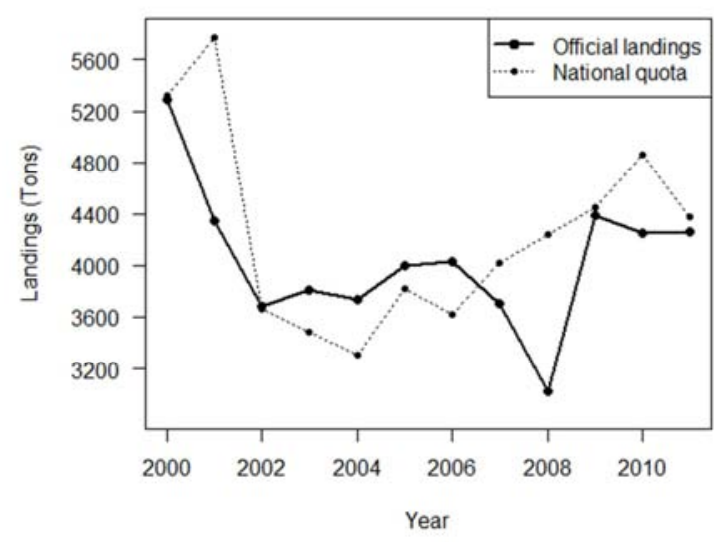

Figure 1b. Evolution of the Bay of Biscay common sole official landings in weight and the national quota (France) between 2000 and 2011.

\subsection{Quota co-management}

Common sole in the Bay of Biscay has been subject to an EU TAC since 1984 that is divided into Member State quotas according to fixed historical keys (Holden, 1994), and the French share accounts for more than $90 \%$. According to the French quota co-management 
system, the national quota is shared out into sub-quotas per PO as defined by legal statutes dating from 2006 (JORF, 2006). The POs are groups of harvesters that manage collectivelygranted fishing allocations. They are geographically-relevant - typically, a PO has its headquarters in a fishing harbor city and most of its members are from the same area, although it is not a rule and there are no area restrictions. They were not established on target species criteria and they usually participate in more than one fishery. The distribution of the national quota between POs is based on the historical landings track records of member producers over the period 2001-2003 (Larabi et al., 2013). PO membership is voluntary and non PO vessels are collectively managed by the administration. In 2011, there were nine POs involved in the Bay of Biscay sole fishery. Since 2008, these POs account for more than 93\% of the total number of vessels operating in the fishery. The main reason why fishermen massively joined POs was that those who remained outside of POs were operating in a racefor-fish where fishery closures could happen early in the season.

The national quota of Bay of Biscay sole was systematically exceeded during 2002-2006 ${ }^{1}$ (Fig. 1b). Because quota overruns yield in penalties through the EU common fishery policy regulations (European Commission, 2009b), POs were brought to make their quota management system evolve and started implementing non-tradeable IVQs systems. This was initiated in 2006 by the largest French PO to optimize the exploitation of their allocated subquota and avoid over-consumption. Indeed, well-defined individual limits were considered easier to enforce than collective limits by PO managers as individual limits allowed for threats of individual penalty to become more meaningful. In 2011, with the increasing sub-quotas constraints, many POs have generalized a limitation system on individual landings for sole at least for the most important producers of sole, which are sole gillnetters. That year, $65 \%$ of the TAC that was managed by non-tradeable IVQs. For the POs that have effectively implemented IVQs systems, quota exchanges or swaps between producers were not allowed, not even within POs. From the authorities' point of view, the law prohibits marketed exchanges of fishing allocations. Whether quota swaps occur between fishers of the same PO is the responsibility of the PO managers. To this day, all French POs have forbidden internal quota swaps between fishers after distribution, although this could be a legally acceptable management option as long as monetary transactions are not involved. The rules for the allocation of IVQs among members of the same PO vary according to POs. They were documented in an exhaustive survey of all Bay of Biscay POs whose results are reproduced in Supplementary Appendix A. The introduction of IVQs is considered as a key element in the limitation of quota overruns and coincides with the official landings not exceeding the national quota during 2007-2011 (Fig. 1b). In the meantime, publicly funded decommissioning schemes were implemented to reduce fleet capacity (Quillerou and Guyader, 2012). Under these programs, historical landings track records attached to the scrapped PO-affiliated vessels were equally reallocated to the so-called $P O$ reserve and national reserve. This mechanism provided the POs with some flexibility in the collective management of their fishing allocations (Larabi et al., 2013). It is worth noting that quota swaps between POs are allowed and such transactions are regulated and recorded by the fisheries authorities. In the institutional context of French fisheries, quota swap refers to a bartering system (without monetary transaction) where a PO can temporarily give away $x$ tons of a quota species to another PO in exchange for $y$ tons of some other quota species. However, swaps between POs have been of limited for the Bay of Biscay sole quota in 2011 and mainly involved non-Bay of Biscay POs that were willing to barter their sole quota they did not need for some other quota that they actually needed.

\footnotetext{
${ }^{1}$ Until 2006, there was no measure regulating the access to the Bay of Biscay sole fishery. Under the sole management plan (European Commission, 2006), a vessel fishing permit system was put in place in 2006 to regulate the entry to the fishery.
} 
Out of the 472 vessels that participated in the sole fishery in 2011, 443 were member of one of the nine POs that spread all along the Bay of Biscay coastline (Fig. 2). The size of the POs ranged from 35 to 490 vessels. Because the constraints and the fleet composition of POs were diverse, their needs in terms of quota management were heterogeneous. Interestingly the three POs that did not implement individual limits (OPPAN, OP Ile d'Yeu and OP Vendée) welcomed sole gillnetters for which more than $40 \%$ of the total gross revenue depended on sole. More generally, the two POs operating in the north of the Bay of Biscay (PMA and OPOB) were mainly composed of trawlers that caught sole as part of a mix of species whereas sole was a more important target species for all other POs. The fleet characteristics by length class and by maritime district are available in Supplementary Appendix A.

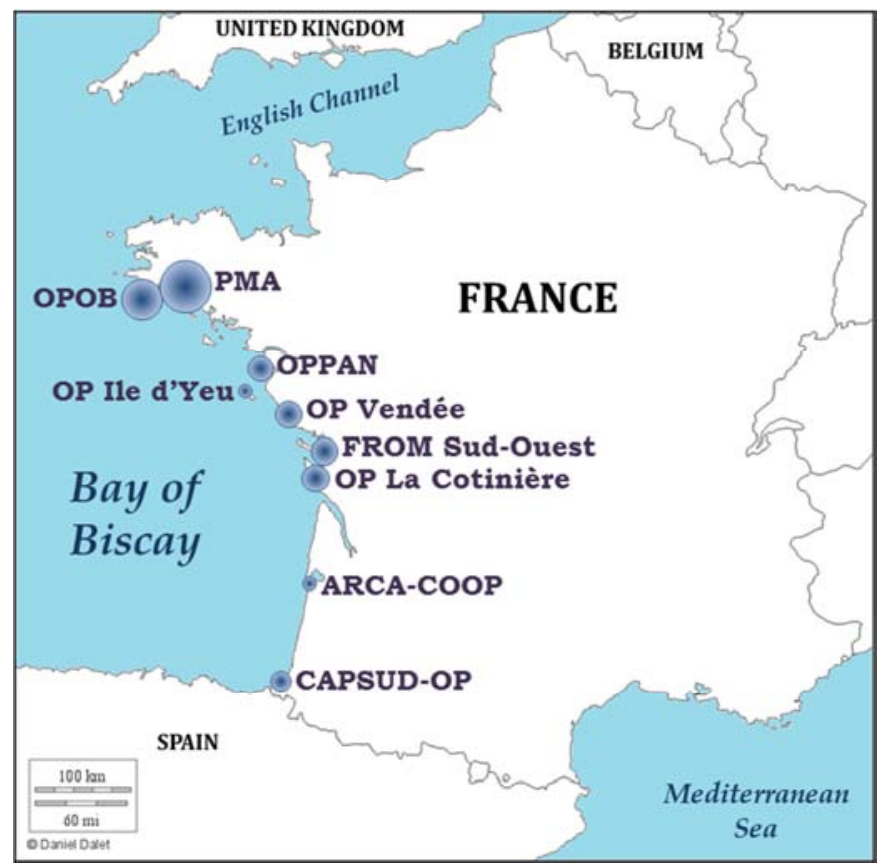

Figure 2. Map of the Producer Organizations in the Bay of Biscay in 2011. Circle size is scaled to the number of vessels operating in the Producer Organization ( $\min =35, \max =490$ ).

\section{Material and methods}

The study of distributional effects of the sole quota management by POs consists in the comparison between how historical landing records are distributed in the fishery with how landings are distributed in the fishery for a given year, considering that the difference is the consequence of the management by POs and their impacts on the strategies of producers. The analysis focused on the year 2011 because it corresponds to the year when IVQ systems were generalized to most POs in the fishery. Besides the actual historical landings records database that was used by the regulator that year was available which was essential for establishing the initial situation.

\subsection{Data and population of reference}

The population of reference is the union (in the mathematical sense of set operation) of all vessels with non-zero Bay of Biscay sole landings in 2011 and all vessels with non-zero historical landings records (including inactive vessels). It is important for the investigation of distributional effects that the population of reference is composed not only of vessels that landed sole in 2011, but also of the vessels that did not land sole but have non-zero historical landings records as they contributed to the collective historical landings of POs and non-PO sector. This population of reference is referred to as "total population" and it is composed of 
1,535 vessels that account for $100 \%$ of the 2011 landings and $89 \%$ of the historical landings records - the remaining $11 \%$ having been placed in the national reserve (2\%) and PO reserves (9\%) after vessel decommissioning.

The data that were used for the analysis included landings, historical landings track records, a fishing activity calendar specifying the types of gear used, vessel length, maritime district and PO membership status for all commercial fishing vessels that operated in the Bay of Biscay (ICES areas VIIIa-b) in 2011. Landings, fishing activity and characteristics of French vessels are compiled in IFREMER's Harmonie database (Leblond et al., 2008). The analysis also used a typology of subfleets based on vessel's fishing activity and landings that has been specifically implemented to study the Bay of Biscay mixed fisheries (Macher et al. 2011). Individual historical landings track records - the basis used by the administration to distribute the French quota among POs - were compiled into a database that contains all vessels with non-zero historical landings records and their PO membership status as of 2011. The vessels with landings greater than $1 \mathrm{t}$ in 2011 accounted for $97 \%$ of the sole production in 2011 and 64\% of the historical landings track records (see Supplementary Appendix A). This difference is actually the first result showing that the system has created flexibility and that there is indeed redistribution between the historical landings track records and the landings observed. The vessels with landings between 0 and $1 \mathrm{t}$ accounted for $3 \%$ of the production and $6 \%$ the historical landings. The total population also included 496 vessels - of which 255 were actually inactive - that had non-zero historical landings records but no sole landings in 2011. These vessels that did not participate in the sole fishery in 2011 were still affiliated to a PO for the most part and contributed to the redistribution towards the 2011 sole fishery vessels.

The historical landings track records database allowed for the computation of the PO subquotas (i.e., the PO shares of the national quota). It also allowed for the simulation of initial vessel allocations based on strict historical landings (SHL vessel limits) that were obtained by multiplying the share of each vessel in the historical landings records by the 2011 TAC. Although they were simulated since the administration does not actually grant individual limits to vessel owners, the SHL vessel limits are relevant because they represent the contribution of each vessel to its PO sub-quota. Therefore SHL vessel limits were considered as the initial distribution and the difference with the landings observed was interpreted as the distributional effects of the quota management by POs. As such, the analysis merged the direct consequences of the way POs administered quotas and their incidental impacts on producers' behavior. Intuitively, the assumption that all changes in distribution could be traced back to management strategies of the POs was straightforward considering the institutional context where POs were exclusively responsible for implementing their own internal allocation rules. Marginally, the fact that the authorities' distribution policy of the national reserve could also have contributed to the distributional effects was overlooked since the national reserve only accounted for $2 \%$ of the historical landings records and was therefore considered as not particularly significant.

\subsection{Inequality metrics and decomposability property of the Theil index}

There are many inequality metrics that are used in social sciences and we considered some of the most well-known ones for the further comparison of the distributions of initial allocations based on historical landings records and the landings observed. A review of pros and cons of the main inequality metrics is proposed in Table 2.

The Gini index is the most commonly used measure of inequality (Gini, 1921) and is a core component of many distributional effects analyses. However there are issues associated with Gini index: the same value may arise from different distribution curves; it is not easily decomposable into subgroups - i.e., it cannot provide relative contributions of subgroups to the inequality in the population. 
Table 2: inequality metrics and their characteristics. $x$ is the income (or the production); $N$ is the size of the population; $\alpha$ is the order of entropy parameter; $\varepsilon$ is the inequality-aversion parameter.

\begin{tabular}{|c|c|c|c|}
\hline & Formula & Pros & Cons \\
\hline Gini index & $G=\frac{\sum_{i=1}^{N} \sum_{j=1}^{N}\left|x_{i}-x_{j}\right|}{2 N^{2} \bar{x}}$ & - Intuitive & $\begin{array}{l}\text { - Not easily } \\
\text { decomposable }\end{array}$ \\
\hline Hoover index & $H=\frac{1}{2 N} \sum_{i=1}^{N}\left|\frac{x_{i}}{\bar{x}}-1\right|$ & - Intuitive & $\begin{array}{l}\text { - Non } \\
\text { decomposable }\end{array}$ \\
\hline Theil index & $T=\frac{1}{N} \sum_{i=1}^{N}\left(\frac{x_{i}}{\bar{x}} \times \ln \frac{x_{i}}{\bar{x}}\right)$ & - Decomposable & - $\quad$ Non intuitive \\
\hline $\begin{array}{l}\text { Generalized entropy } \\
\text { index }\end{array}$ & $G E(\alpha)=\frac{1}{N \alpha(\alpha-1)} \sum_{i=1}^{N}\left[\left(\frac{x_{i}}{\bar{x}}\right)\right.$ & - Decomposable & $\begin{array}{l}\text { - } \quad \text { Non intuitive } \\
\text { Parameter to be } \\
\text { set }\end{array}$ \\
\hline Atkinson index & $A(\varepsilon)=1-\frac{1}{\bar{x}}\left(\frac{1}{N} \sum_{i=1}^{N} x_{i}^{1-\varepsilon}\right.$ & $\begin{array}{l}\text { - Sensitivity to } \\
\text { upper/lower end }\end{array}$ & $\begin{array}{l}\text { - Parameter to be } \\
\text { set }\end{array}$ \\
\hline $\begin{array}{l}\text { Herfindahl-Hirschman } \\
\text { index }(\mathrm{HHI})\end{array}$ & $H H I=\sum_{i=1}^{N}\left(\frac{x_{i}}{\sum_{j=1}^{N} x_{j}}\right)^{2}$ & $\begin{array}{l}\text { - Applicable in a } \\
\text { variety of contexts }\end{array}$ & $\begin{array}{l}\text { - } \quad \text { Correlated with } \\
\text { number of firms }\end{array}$ \\
\hline
\end{tabular}

The review of the various inequality metrics allowed to identify an index that proved to be particularly useful for the analysis: the Theil index (Theil, 1967). Despite not being as intuitive as the Gini, the Theil index has an interesting decomposability property: it is a weighted average of inequality within subgroups, plus inequality among those subgroups (Bourguignon, 1979). If the population is divided into $m$ subgroups and $s_{j}$ is the income share of subgroup $j, T_{j}$ is the Theil index for that subgroup, and $\bar{x}_{j}$ is the average income in subgroup $j$, then the Theil index can be rewritten as:

$$
T=\sum_{j=1}^{m} s_{j} \times T_{j}+\sum_{j=1}^{m} s_{j} \times \ln \frac{\overline{x_{j}}}{\bar{x}} .
$$

The contribution of the subgroup $j$ to the total inequality $T$, sometimes referred to as the within subgroup $j$ component, is $s_{j} \times T_{j}$. The contribution of the inequality among subgroups to the total inequality, also known as the between component, is $\sum_{j=1}^{m} s_{j} \times \ln \frac{\overline{x_{j}}}{\bar{x}}$.

\subsection{Quantifying distributional effects}

The Theil index measures an entropic distance between the observed distribution and the perfect equality distribution. Its decomposition uses the notion of within- and between-groups components that relates to similar concepts often encountered in statistical analysis. For instance, ANOVA models use the variation within and between groups to provide a statistical test to determine if the observed differences in means can be attributed to the natural variations in the population. Likewise, intra-cluster variance and inter-cluster distance are the core concepts behind cluster analysis techniques such as $k$-means clustering and hierarchical clustering. In the study of distributional effects, the decomposition of the Theil index appears as a well-suited quantitative tool to identify which groups contribute most to the total inequality. When comparing two situations, changes in the within and between group components indicate that distributional effects have happened. However, it does not provide direct information about the mean of a specific group relative to the other groups or to the overall mean. Similarly, if the contribution of one specific group to the Theil index is found to 
have decreased between two situations, it indicates that the distribution of what is being measured has become more homogeneous (thus distributional effects have happened), but it does not convey any information about a potential change in mean. Only the between groups component is linked to the differences in means between the different groups. A similar argument could be made about the other inequality metrics presented in Table 2: they essentially measure variability, but do not quantify trends. Hence it is important that an analysis of distributional effects not only rely on inequality metrics, but also include some measurement of changes in mean or sum per group. When the composition of the different groups remains unchanged between the two situations that are being compared, both the mean and the sum provide some information about the trend. The sum provides a global overview of where in the fishery cumulative differences are the most important. However it can overlook potentially interesting changes in mean that may occur in small groups. Conversely, the mean may focus attention on small groups containing an outlier while obscuring more interesting aggregate trends in larger groups. Hence the quantification of distributional effects may include both the mean and sum per group as complementary measurements of trends. Visual representations based on the sum and capturing group size aspects (such as the ones proposed in this paper) can also be convenient to apprehend these different scales simultaneously.

\subsection{Methods for the study of distributional effects in the Bay of Biscay sole fishery}

The analysis involved the comparison between an initial situation and a final situation at different scales. The initial situation is the SHL vessel limits, i.e. the simulated individual allocations computed as the share of each vessel in the historical landings records (20012003) multiplied by the 2011 TAC. The final situation is the landings that were observed by vessel in 2011. The first hypothesis to be tested is whether the quota management by POs has contributed to greater equity in some dimension. All inequality metrics presented in the Table 2 were computed at the total population level on both distributions. It was undetermined what to expect at this scale because the concentration of production that might have occurred following the decommissioning schemes and the reduction of the number of vessels in the fishery might have been balanced or overweighed by the POs' apparent disposition to maintain access to the resource of local fishing communities. Then fleet segmentations were used to bring the analysis to a more disaggregated level. The analysis covered 3 dimensions:

- Fishing gear, which was related to the fact that some POs had recourse to separated quota management according to the fishing gear used to manage conflicts arising from different quota consumption behaviors

- Vessel length, which was related to the contrasting attitudes POs have had towards the membership of small-scale vessels in the past and the issue of equity of access to the resource in a context where small-scale vessels claimed their historical landings records were underestimated by the fisheries administration

- Maritime district, which related to the strong local roots of POs and access to the resource of local fishing communities.

The Theil index was used to determine the within and between components for each of these dimensions. It was expected that the quota management by POs may have contributed to greater equity within some subgroups of vessels as some of the allocation criteria used by POs were based on the fishing gear, the vessel length or territorial aspects.

Next, for each PO $k$ and fleet segment $j$, the cumulative difference $C D_{k j}$ between landings observed and SHL vessel limits was also computed as:

$$
C D_{k j}=\sum_{i \in(k \cap j)}\left(\text { Landings }_{i}-\text { SHL vessel limits }{ }_{i}\right)
$$


where the subscript $i$ represents the individual vessels. The cumulative difference by subgroup is complementary to the decomposition of the Theil index as it may reveal distributional changes such as differences in means between the different groups that are unrelated to concentration of production. As such, the cumulative differences were intended to determine which subgroups of vessels actually benefited from the flexibility that the system created and it was expected that the subgroup trends (increase or decrease) would vary according to the PO since POs had contrasting quota management strategies. Lastly, KruskalWallis non-parametric tests (Kruskal and Wallis, 1952) were applied to measure the statistical significance of the differences among the subgroup mean differences computed as $\mu_{k j}=\frac{C D_{k j}}{N_{k j}}$ where $N_{k j}$ is the number of vessels in the PO $k$ and fleet segment $j$.

\section{Results}

\subsection{Application of inequality metrics at the total population level}

The various metrics that were applied to the SHL vessel limits and the observed landings distributions at the total population level as well as some baseline index values are presented in Table 3. These indices clearly indicated that both distributions were intrinsically very concentrated. This result was not a surprise since the population of reference contained many vessels with very few historical landings or few landings observed. All metrics showed the same tendency, namely that the landings observed were slightly less concentrated than the SHL vessel limits. This result was consistent across all indices as there was no outstanding value. However, for each index, the difference between the index values for the historical landings records and the landings observed distributions was rather small. Therefore it was concluded that there was no clear sign of distributional effects at this scale, i.e., the quota management by POs did not clearly reduce concentration at the total population level (nor did it increase it).

Table 3. Application of inequality metrics to the distributions of Strict Historical Landings (SHL) vessel limits and Landings observed. Perfect equality distribution is the baseline value when all individuals have the same landings. Two-levels 75-25 distribution is a simulated distribution where one half of the population equally shares $75 \%$ of all landings and the other half of the population equally shares the remaining 25\%. Maximal inequality distribution is when one individual has all landings, and all others have none.

\begin{tabular}{lccccc}
\hline & $\begin{array}{c}\text { SHL vessel } \\
\text { limits (based } \\
\text { on historical } \\
\text { landings) }\end{array}$ & $\begin{array}{c}\text { Landings } \\
\text { observed }\end{array}$ & $\begin{array}{c}\text { Perfect } \\
\text { equality } \\
\text { distribution }\end{array}$ & $\begin{array}{c}\text { Two-levels } \\
\mathbf{7 5 - 2 5} \\
\text { distribution }\end{array}$ & $\begin{array}{c}\text { Maximal } \\
\text { inequality } \\
\text { distribution }\end{array}$ \\
\hline Gini index & 0.87 & 0.86 & 0 & 0.25 & 1 \\
\hline Hoover index & 0.73 & 0.72 & 0 & 0.25 & 1 \\
\hline Theil index & 1.77 & 1.76 & 0 & 0.13 & 7.33 \\
\hline $\begin{array}{l}\text { Generalized entropy } \\
\text { index }(\alpha=2)\end{array}$ & 4.82 & 4.72 & 0 & 0.12 & 767 \\
\hline $\begin{array}{l}\text { Atkinson index } \\
(\varepsilon=0.75)\end{array}$ & 0.93 & 0.93 & 0 & 0.10 & 1 \\
\hline $\begin{array}{l}\text { Herfindahl-Hirschman } \\
\text { index (HHI) }\end{array}$ & 0.0069 & 0.0068 & 0.00065 & 0.00081 & 1 \\
\hline
\end{tabular}




\subsection{Decomposition of the inequality by groups of vessels}

The decomposability property of the Theil index was used to compute the contributions of different fleet segments to the inequality in the distributions of SHL vessel limits and Landings observed (Figs 3a-c). A small contribution of a subgroup indicates that the distribution within the subgroup is homogeneous, and conversely. The between groups component indicates the importance of the contribution of the differences between subgroup means in the total inequality.

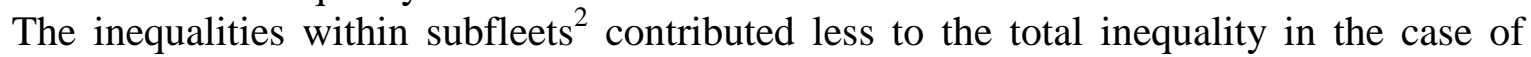
landings observed than for SHL vessel limits (Fig. 3a). Indeed, the between groups component (in black) was more important in the landings than in the SHL limits. This means that the quota management by POs implied landings within subfleets being more homogeneous than the historical landings.

The decomposition of the inequality by length class (Fig. 3b) allowed an assessment of whether the quota management system impacted distribution towards the small scales fisheries. The inequality between groups was found less important than in the case of decomposition by fleets, which means that historical landings and the landings observed were both not very homogeneous within length classes. Besides, the inequalities among the $>20 \mathrm{~m}$ vessels as well as among the $<10 \mathrm{~m}$ vessels were slightly greater for the landings than for SHL vessel limits, which was compensated - in the sense that the total inequality in both distributions were about the same - by the between groups component being slightly greater for the SHL vessel limits than for the landings.

The decomposition of the inequality by maritime district (Fig. 3c) allowed an investigation whether regional equilibriums were preserved in the fishery. One notable outcome was that vessels operating in the north of the Bay of Biscay, i.e. from Morlaix to Vannes, contributed for only a small part of the total inequality in both the landings and the SHL vessel limits distributions, whereas vessels operating in the south contributed for the most part of the inequality. Comparing the landings to the SHL limits, inequalities marginally increased in L'Ile d'Yeu, Les Sables d'Olonne and La Rochelle, and decreased in SaintNazaire, Noirmoutier and Marennes.

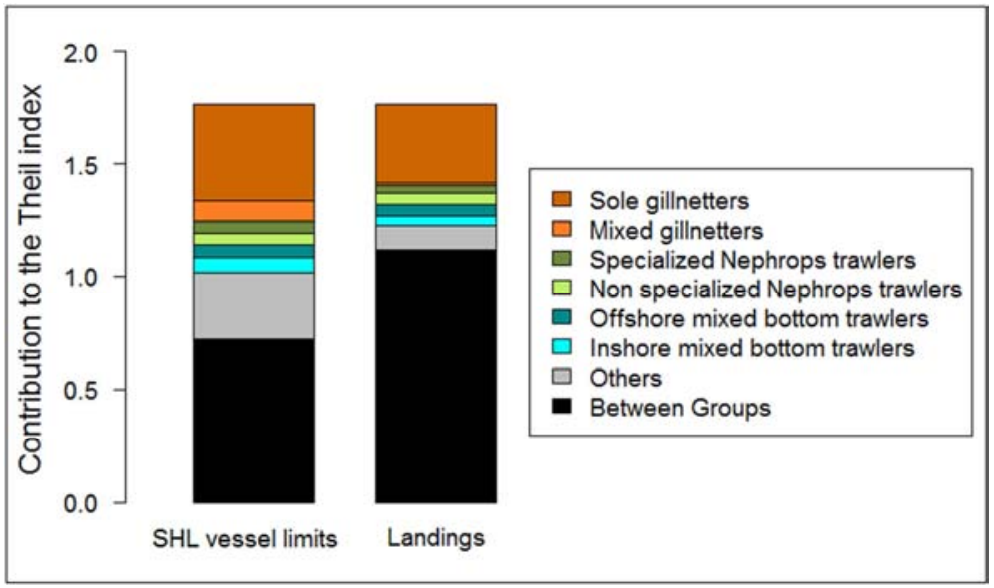

Figure 3a. Decomposition of inequality in the distributions of Strict Historical Landings (SHL) vessel limits and Landings observed: contributions to the Theil index by subfleet

\footnotetext{
${ }^{2}$ The typology of subfleets used was specifically implemented to study the Bay of Biscay mixed fisheries (Macher et al. 2011).
} 


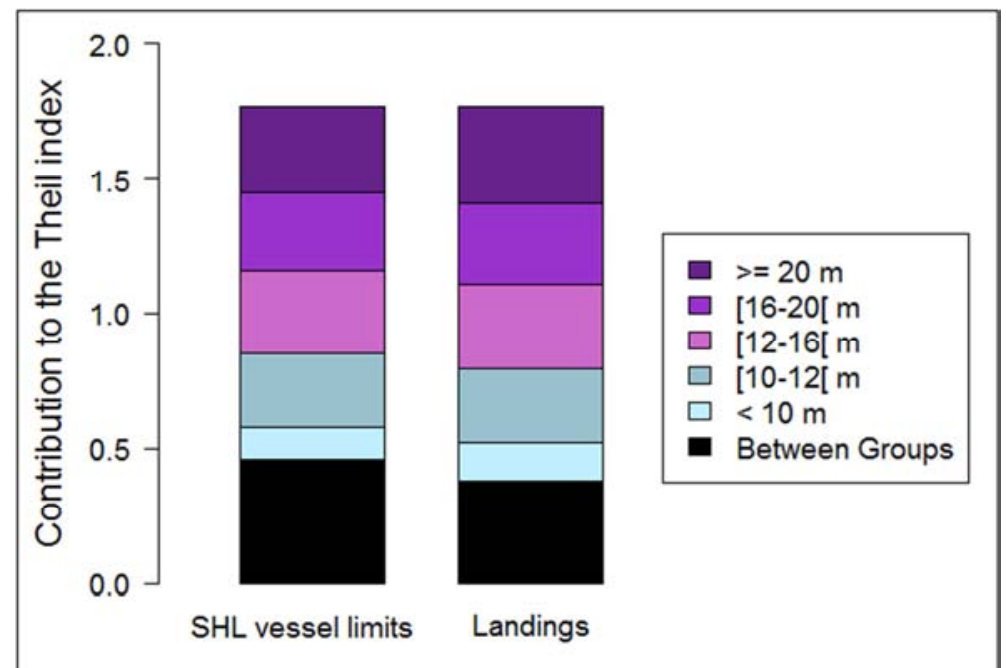

Figure 3b. Decomposition of inequality in the distributions of Strict Historical Landings (SHL) vessel limits and Landings observed: contributions to the Theil index by length class

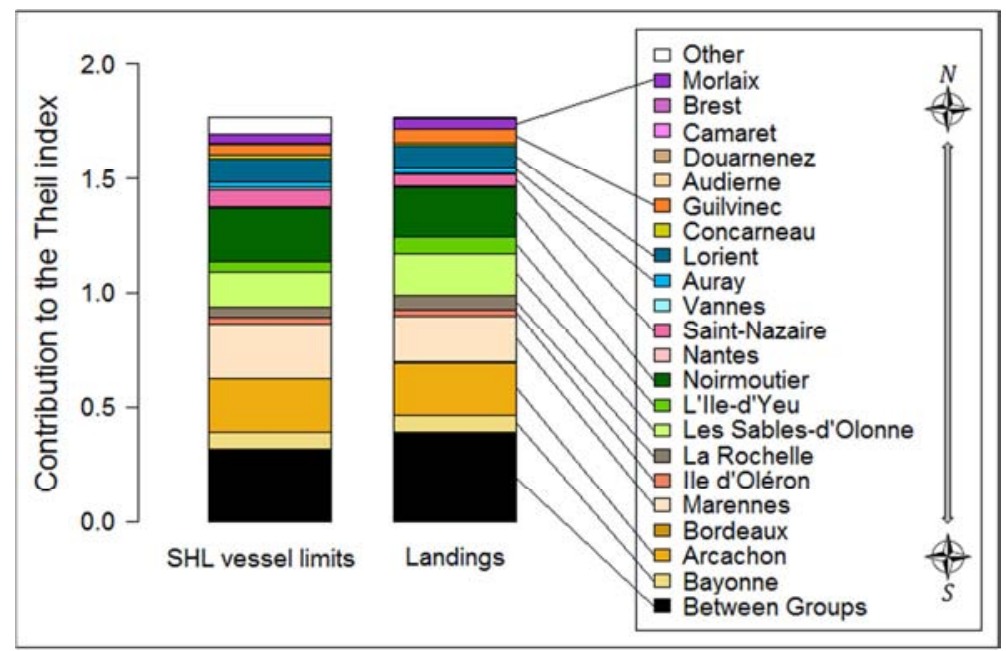

Figure 3c. Decomposition of inequality in the distributions of Strict Historical Landings (SHL) vessel limits and Landings observed: contributions to the Theil index by maritime district

\subsection{Cumulative difference by groups of vessels}

In 2011, the sum of landings exceeded the sum of SHL limits in the total population because SHL limits do not account for the national and PO reserves of historical landings track records. Consequently the graphs of the cumulative difference between landings and SHL vessel limits (Figs 4a-c) were dominated by positive differences in favor of landings. The red circles indicate that the sum of the landings observed for the vessels belonging to the corresponding fleet segment and PO was more important than the sum of their SHL vessel limits. In other words, the red circles indicate the "winning" subgroups in a PO and the blue circles indicate the opposite, and the size of the circles corresponds to the number of vessels belonging to the corresponding PO subgroup.

The landings by sole gillnetters and by non-specialized nephrops trawlers - i.e. the fleets with the greatest sole landings per vessel and for which the gross revenue was most dependent on sole - were greater than their SHL limits, at least at an aggregated scale (Fig. 4a). Conversely, the sole landings by mixed gillnetters and by the fleet "Others" were less than their SHL limits. This means that the quota management system either incentivized them to 
change their fishing strategies, e.g. through PO fishing plans, or restrained their possibility to catch sole while potentially offering alternative fishing opportunities on other target species thanks to the PO track records pooling mechanism.

There were some POs in which the vessels smaller than $12 \mathrm{~m}$ benefited from the sole quota management system (Fig. 4b). These are POs that are dominated by small-scale vessels. While the decomposition of the Theil index by vessel length class indicated that landings were slightly less homogeneous than SHL vessel limits among the $>20 \mathrm{~m}$ vessels, the cumulative difference suggests that this is due to a sensible increase in landings for the bigger vessels in a few POs.

With POs being geographically-relevant entities, it was not surprising that for most POs the greatest positive cumulative difference was observed in their main maritime district in terms of number of vessels (Fig. 4c). Notably the maritime districts that were previously identified for their marginal inequality increases and decreases actually corresponded to maritime districts where essentially only one PO operates. As for the non-Bay of Biscay PO vessels that were part of the total population and appeared as having negative cumulative difference, they were vessels that used to operate in the Bay of Biscay during the historical landings period but had moved outside of the Bay of Biscay as of 2011.

The statistical significance of the differences among the subgroup mean differences between landings observed and SHL vessel limits was tested with the Kruskal-Wallis oneway test along the subfleet, vessel length class, and maritime district dimensions. Each of these factors taken independently were found statistically significant ( $p$-value $<10^{-3}$ ), i.e. for each dimension the test rejected the null hypothesis of the factor having no effect on the subgroup mean differences between landings observed and SHL vessel limits. The outcomes of these tests were therefore in line with the expectation that the quota management by POs contributed to significant distributional changes in the above-mentioned dimensions.

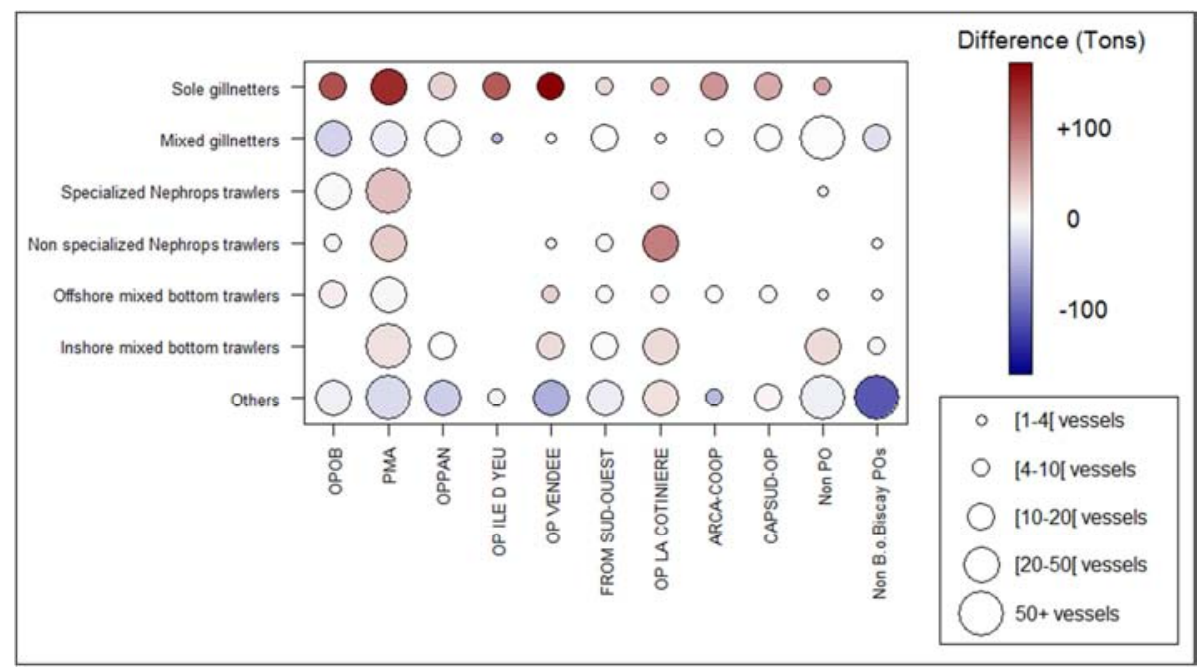

Figure 4a. Cumulative difference between Landings observed and Strict Historical Landings (SHL) vessel limits in 2011 by subfleet (in row) and Producer Organization (in column). Red circles (resp. Blue circles) indicate that the sum of the landings observed (resp. SHL limits) by vessels belonging to the corresponding subfleet and PO was more important than the sum of their SHL limits (resp. landings observed). Color is scaled to the maximum absolute value. Circle size corresponds to the number of vessels belonging to the corresponding fleet and $\mathrm{PO}$. 


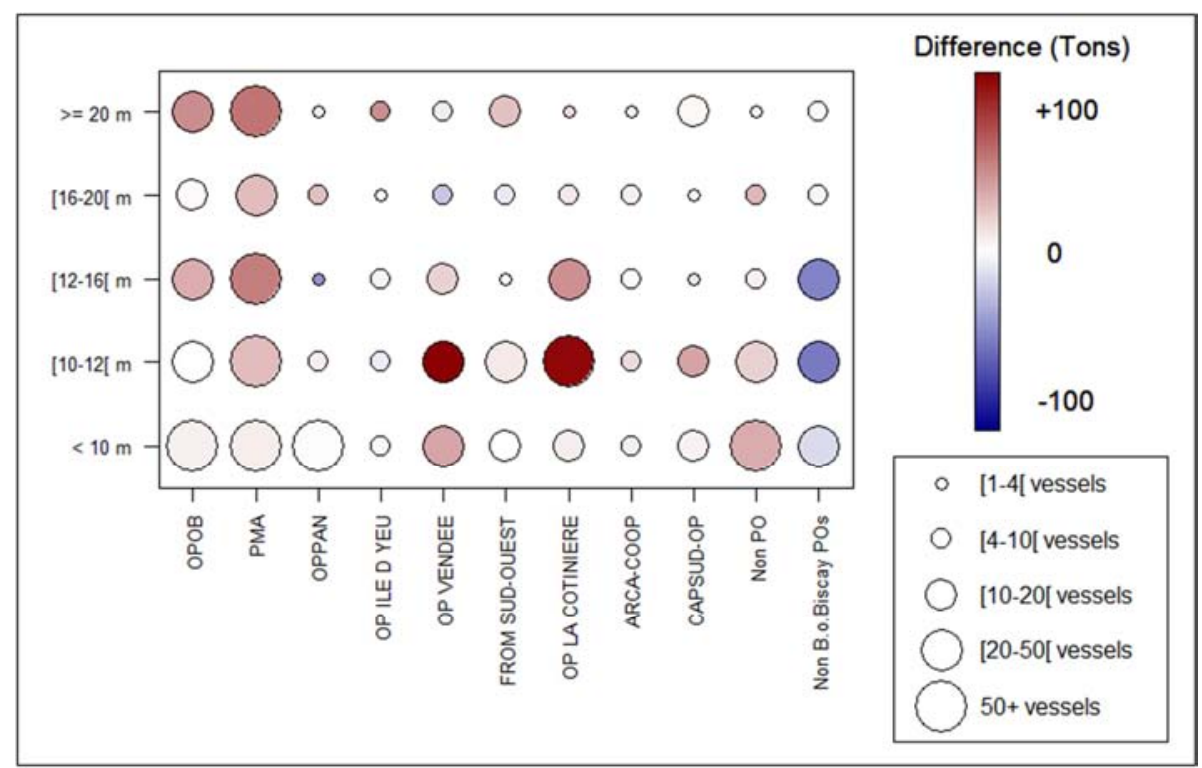

Figure 4b. Cumulative difference between Landings observed and Strict Historical Landings (SHL) vessel limits in 2011 by length class (in row) and Producer Organization (in column). Red circles (resp. Blue circles) indicate that the sum of the landings observed (resp. SHL limits) by vessels belonging to the corresponding length class and PO was more important than the sum of their SHL limits (resp. landings observed). Color is scaled to the maximum absolute value. Circle size corresponds to the number of vessels belonging to the corresponding length class and PO.

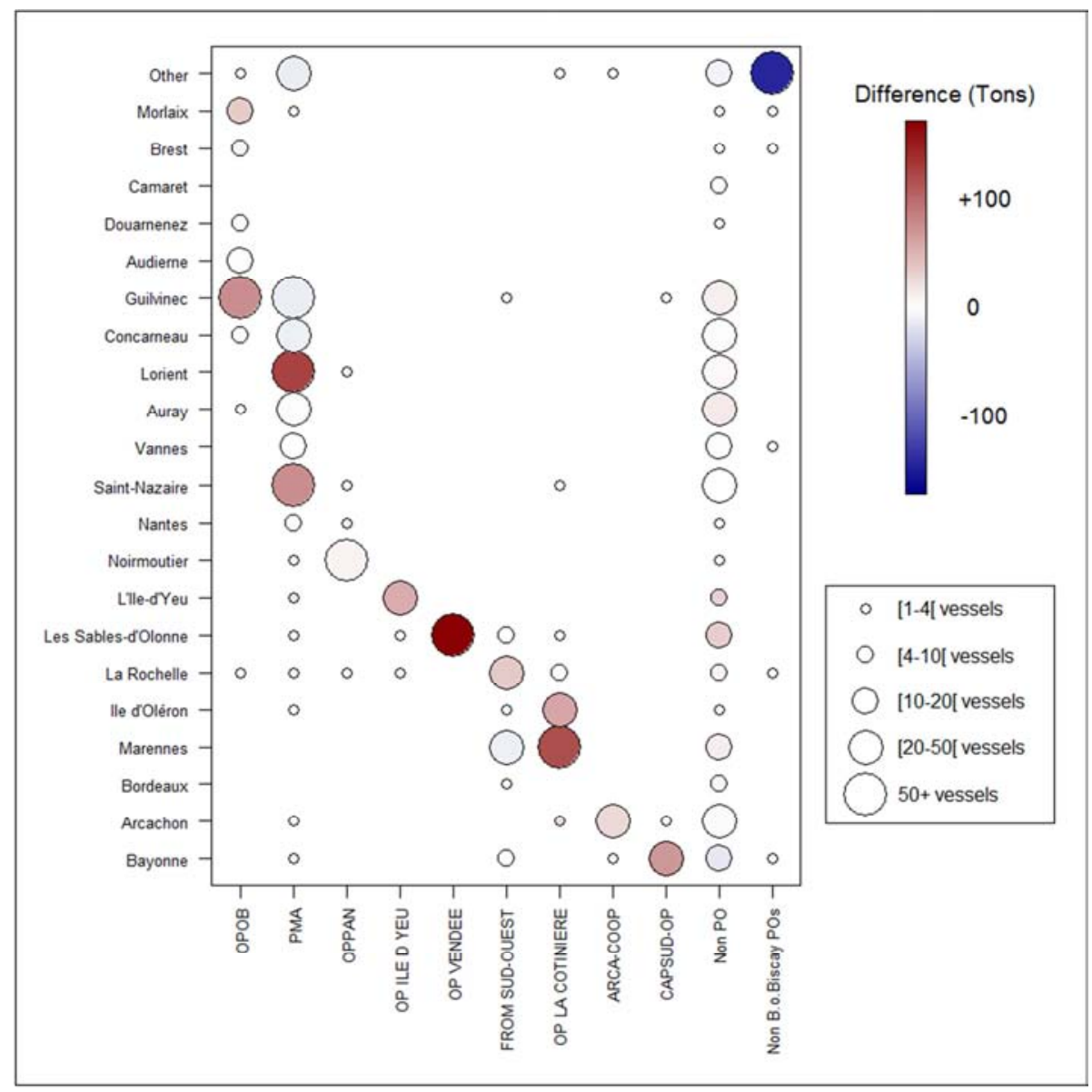

Figure 4c. Cumulative difference between Landings observed and Strict Historical Landings (SHL) vessel limits in 2011 by Maritime District (in row) and Producer Organization (in column). Red circles (resp. Blue circles) indicate that the sum of the landings observed (resp. SHL limits) by vessels belonging to the corresponding length class and PO was more important than the sum of their SHL limits (resp. landings observed). Color is scaled to the maximum absolute value. Circle size corresponds to the number of vessels belonging to the corresponding maritime district and PO. 


\section{Discussion}

\subsection{Preventing concentration of production while reducing fleet capacity}

A typical ITQ system generally induces a rationalization of the fishing fleet capacity to increase economic yield. The switch from a "derby" fishery to an ITQ generates a decrease of the number of vessels that operate in the fishery, and quota sellers or leasers behave rationally according to economic objectives that can be contradictory to maintaining social values. Direct consequences are the concentration of the production and the reduction of employment in the harvesting sector (Squires et al., 1995). Ultimately, the benefits of higher economic efficiency tend to flow to owners who may not be fishermen themselves (Pálsson and Helgason, 1995; Pinkerton and Edwards, 2009) and territorial socio-economic equilibriums may be threatened if quotas can be transferred from one region to another. Although safeguard clauses may be adopted to prevent some of the negative social impacts of an ITQ (Kroetz and Sanchirico, 2010), it appears that concentration of production does occur in most ITQ systems (Abayomi and Yandle, 2012; Hamon et al., 2009; Clay et al., 2014; Matthíasson et al., 2015).

The originality of the French case study is that an input control policy (EU funded decommissioning schemes) was combined with an output management system (allocations by POs) and resulted in an adjustment of the fishing capacity without aggravating the problems of wealth concentration. Decommissioning schemes indeed allowed the number of vessels in the Bay of Biscay sole fishery to decrease by $20 \%$ over 10 years. At the same time, the quota allocation system, based on several POs spread along the coastline with specificities in terms of quota management strategies that they can adapt to their fleet composition, aimed at maintaining economic and social equilibriums. The results showed that concentration did not occur. To this regard, the French management system, that combines a track records pooling mechanism to provide collective allocations to POs and redistribution between members and unique controls on tradeability of catch shares, successfully managed to avoid some of the social issues that tend to happen in an ITQ while reducing the fishing capacity through decommissioning schemes.

\subsection{Room for maneuver in a context of non-transferability}

There are several reasons that can explain how distributional effects have occurred in the Bay of Biscay sole fishery even though quota trades between individuals are prohibited. One of the main sources of flexibility in the quota management system comes from the PO reserves of historical landings track records that were introduced alongside decommissioning schemes. These reserves, which are directly managed by the POs, add to the collective historical landings each member brings to the POs and are meant to support new entrants to the fishery and established PO members. Likewise, the national reserve gives the administration room to maneuver in the management of the non PO vessels. Furthermore, it used to be considered that POs that exceeded their allocation would not face sanctions unless the national quota was exceeded too, thus the national reserve could also give flexibility to the PO that were careless with their sub-quota consumption. Further flexibility originated from the non-Bay of Biscay PO vessels. Having conserved their historical landings track records while being outside of the fishery in 2011, these vessels effectively contributed to quota reallocation in the fishery. Indeed, quota swaps between POs are allowed and POs that have some quota they do not need are usually willing to exchange it for some quota that they actually need. Thus it is not uncommon to observe quota swaps between POs that happen on a regular basis.

\subsection{Allocation systems and equity}

In a catch share program, the initial allocation plays a major part in determining how wealth is distributed among individuals. The French quota management system mainly relies 
on grandfathering as catch shares that are allocated to POs are based on historical landings of their members. However, each PO developed their own internal rules for providing individual or collective allocations to their members which sometimes involve alternatives to grandfathering methods such as gear-based or equal-sharing rules (see Supplementary Appendix A for the details of the allocation criteria used by POs). As the French system does not allow for quota trades between individuals, not even within POs, the design of PO internal allocation rules has a direct influence on individual strategies and economic performances of PO members. The rules that have been adopted by POs are heterogeneous and exhibit the variety of the fishing fleet profiles across POs. The results showed that the redistribution of the sole quota significantly benefited the fleets that were the most economically dependent on this species. Thus, in a context of non-transferability of fishing allocations, the POs played the role of quota fine-tuning to adjust for the subfleets needs. This was essentially achieved through three distinct (but non-exclusive) mechanisms: setting allocation rules based on reference years that are more recent than the historical landings track records period (used in three POs); securing distinct collective catch shares for one or more specific subfleets determined by gear-based, vessel length and/or geographical criteria (respectively in three, one and three POs); and differentiating allocation rules for one or more specific subfleets (in five POs). This later type of allocation methods includes equal-sharing rules (in two POs) that presumably contributed to reduce inequalities within subfleets (Fig. 3a).

In certain POs, management policies were also favorable to small-scale fisheries $(<12 \mathrm{~m})$ and local fishing communities. At first sight, it appears that this is not directly linked to some internal allocation rule specifically designed to favor small-scales. Rather, this can be explained by the fact that, in the past, the landings of small-scale vessels were not systematically recorded as the compliance with landings declarations requirements could be deficient and the use of logbooks was mandatory for large-scale vessels only. This consequently led the administration to underestimate their historical landings in the years 2001-2003. Their cumulated landings thus exceeded their cumulated SHL vessel limits. However, this is still relevant to the distributional effects of the management by POs as it is a consequence of POs strategies regarding the membership of small-scale vessels that did not have historical landings track records and allowing them to stay in the fishery by granting them a share of the PO sub-quota. This is actually critical as addressing participants who may not have catch history records but have historically caught fish in the fishery is considered as one of the main concerns about fairness when allocations are based on historical catch (Lynham, 2014).

The territorial dimension also appears to have influenced the allocation strategies chosen by POs. Results established that the redistribution of the sole quota primarily benefited the vessels operating in the maritime district where POs have their headquarters (Fig. 4c) and constituting the subfleets that are historically linked to the POs "identity". Thus, the participatory decision-making process that determines the allocation rules seems to be influenced by PO's local roots and predominant subfleets. Concretely, local differentiations can be directly established in the design of allocation rules through geographically-based criteria or indirectly by using gear-based criteria that designate specific subfleets that essentially operate in a particular area. The results also indicated that distributional effects among non-PO vessels were minor. In fact, the non-PO vessels remained in a common pool supervised by the administration where a race-for-fish is still happening. This explains why most historical landings records holders were incentivized to join POs.

Although the system in place prevented the concentration of production and contributed to greater equity in some dimensions, inequalities between subfleets, both within and across POs, are still important. As a matter of fact, the question of equity between POs is still being asked by many stakeholders. Some small-scale POs consider that the larger-scale POs 
benefited from having vessels eligible to the decommissioning schemes. These small-scale POs further denounced the strict membership policy adopted by the larger-scale POs that denied membership to participants without track records, which they claim was not fair to the small-scale participants (although it was efficient in making the larger-scale PO members benefit from the possibilities they acquired thanks to the decommissioning schemes). Some POs invariably complain about the use of historical landings as the basis for sub-quota assignments and a potential contradiction with antitrust laws (Autorité de la concurrence, 2015).

Some stakeholders also expressed their concerns about inter-generational equity. To address this issue, a "tax system" on track record transfers associated with vessel transactions has recently been implemented (Code rural et de la pêche maritime, 2014). The taxed track records are first assigned to the national and PO reserves and are then meant to be reallocated to young fishermen who do not currently have track records to support the rejuvenation of the fishery participants. In practice, the system is quite new and as of now the taxed track records mainly benefit already established PO members by increasing the POs' collective allocations. Although this new measure demonstrates a real effort towards improving inter-generational equity, the access to the fishery remains very restrained.

In conclusion, even if the system has prevented an increased concentration of production that could have resulted from the reduction of the fleet size, inequalities are still important and many stakeholders call for an evolution of the allocation system towards greater equality and transparency. To this regard, the co-management approach in place, where fishermen actively participate to the decision-making process, appears as a means of implementing the rules that can lead to such further changes.

\subsection{Limits and perspectives}

Further developments in the analysis of the Bay of Biscay sole fishery case study could be considered due to the following limitations:

- the analysis focused on the sole quota distribution could be integrated into a multispecies analysis as most vessels actually operate in more than one fishery. In addition to the distribution of the sole historical landings track records and landings, a multispecific analysis would highlight which groups of vessels were globally advantaged and disadvantaged by taking into account potential compensations among species. Such analysis is reserved for future work.

- the analysis was carried out at the vessel level while distributional effects are usually considered at the firm level. Since most firms operating in the Bay of Biscay actually own only one vessel, this approximation is in fact likely to have only minor implications on the outcomes.

- inequality metrics were applied to production while it is more common to apply them to income.

The perspectives in this case study also include a comparison with the individual quotas vessels were allocated by their PO: the difference between the SHL vessel limits and the individual quotas should highlight the effects of the quota management by POs on the initial distribution, and the difference between the individual quotas and the landings observed should provide information on how well-balanced individual quotas and landings are. An analysis of the performance in terms of equity of the alternative allocation rules used in distinct POs would certainly be valuable to make more explicit which allocation rule is best to favor equity for a particular subfleet profile. However, comparisons between POs are not straightforward as each PO uses a different fleet segmentation to differentiate allocation rules for one or more specific subfleets (Supplementary Appendix A). Therefore, it appears that 
more data such as historical landings and allocation rules for other species or for different years is needed to develop this type of analysis.

\section{Conclusion}

This paper includes for the first time the use of the decomposability property of an inequality metric in an empirical study of distributional effects of fishing quota management systems. The analysis showed how the decomposition of the inequality by subgroups can provide useful insights for the description and interpretation of the dynamics of the fishery. This approach appears to be particularly relevant in cases where the distributional effects cannot be observed at the global scale and where distributional issues are concerned with multiple dimensions such as social and territorial issues. This approach, coupled with some measurement of subgroup trends, appears as an effective framework for the analysis of distributional effects and could for example be utilized to improve the understanding of the impacts of the allocation method used in a new catch share program.

The analysis that was carried out in this paper was primarily concerned with equity and the results showed that the current French fishing allocation system tends to maintain preexisting territorial and socio-economic equilibriums due to the management operated at the PO level. Beyond issues of equity, the economic efficiency of the allocation system must also be assessed. Tradeoffs between economic efficiency and social issues are one of the largest challenges of fisheries management. In France, fishermen who want to acquire more quota than they have are currently constrained by the non-transferability rule. Besides, the institutional context is evolving with the last CFP reform introducing a discard ban. This reform may challenge the efficiency of the current quota management system and increase the need for quota tradeability, so that the quota management objectives and means may be brought to evolve further in the near future.

\section{References}

Abayomi, K., Yandle, T., 2012. Using conditional Lorenz curves to examine consolidation in New Zealand commercial fishing. Mar. Res. Econ. 27(4), 303-321.

Adelaja, A., Menzo, J., McCay, B., 1998. Market power, industrial organization and tradeable quotas. Rec. Indust. Org. 13(5), 589-601.

Aranda, M., Murillas, A., 2015. Allocation of fishing possibilities, incentives and outcomes: Insights from Basque fishermen's organisations in Spain. Mar. Pol. 61, 171-178.

Armstrong, C.W., Clark, D.J., 1997. Just fishing? Equity and efficiency in fisheries management regimes. Mar. Res. Econ. 12(3), 203-220.

Asche, F., Eggert, H., Gudmundsson, E., Hoff, A., Pascoe, S., 2008. Fisher's behaviour with individual vessel quotas-Over-capacity and potential rent: Five case studies. Mar. Pol. 32(6), 920-927.

Autorité de la concurrence, 2015. Avis n $15-\mathrm{A}-19$ du 16 décembre 2015 relatif aux effets sur la concurrence du mécanisme de répartition des quotas de pêche en France. Autorité de la concurrence, République Française, available online at http://www.autoritedelaconcurrence.fr/pdf/avis/15a19.pdf

Bourguignon, F., 1979. Decomposable income inequality measures. Econometrica, 901-920.

Branch, T.A., 2009. How do individual transferable quotas affect marine ecosystems? Fish and Fisheries 10(1), 39-57.

Bromley, D.W., Bishop, R.C., 1977. From Economic Theory to Fisheries Policy: Conceptual Problems and Management Prescriptions. In Economic Impacts of Extended Fisheries Jurisdiction. L.G. Anderson, ed. Ann Arbor MI: Ann Arbor Science Publishers. 
Clay, P.M., Kitts, A., Pinto da Silva, P., 2014. Measuring the social and economic performance of catch share programs: Definition of metrics and application to the U.S. Northeast Region groundfish fishery. Mar. Pol. 44, 27-36.

Code rural et de la pêche maritime, 2014. Article R921-45, décret n²014-1608 du 26 décembre 2014. Available online at https://www.legifrance.gouv.fr/ affichCode.do?cidTexte=LEGITEXT000006071367

Connor, R., 2000. Trends in fishing capacity and aggregation of fishing rights in New Zealand under individual transferable quotas. FAO Fisheries Technical Paper, (2), 267-278.

Copes, P., 1986. A critical review of the individual quota as a device in fisheries management. Land Econ. 62(3), 278-291.

Copes, P., Charles, A., 2004. Socioeconomics of Individual Transferable Quotas and Community-Based Fishery Management. Agr. Resource Econ. Rev. 33, 171-181.

Costello, C., Gaines, S.D., Lynham J., 2008. Can catch shares prevent fisheries collapse? Science, 321(5896), 1678-1681.

Daurès, F., Rochet, M.J., Van Iseghem, S., Trenkel, V.M., 2009. Fishing fleet typology, economic dependence, and species landing profiles of the French fleets in the Bay of Biscay, 2000-2006. Aquat. Living Resour. 22(04), 535-547.

Deacon, R.T., 2012. Fishery management by harvester cooperatives. Rev. Env. Econ. Policy 6(2), 258-277.

Dupont, D.P., Phipps, S.A., 1991. Distributional consequences of fisheries regulations. Can. J. Econ. 206-220.

European Commission, 2006. Council regulation No 388/2006 of 23 February 2006 establishing a multiannual plan for the sustainable exploitation of the stock of sole in the Bay of Biscay. Official journal of the European Union L 65/1 7.3.2006

European Commission, 2009a. Green Paper: Reform of the Common Fisheries Policy. COM (2009) 163 final, $28 \mathrm{pp}$.

European Commission, 2009b. Council regulation No 1224/2009 of 20 November 2009 establishing a Community control system for ensuring compliance with the rules of the common fisheries policy. Official journal of the European Union L 343/3 22.12.2009

European Commission, 2010. Synthesis of the Consultation on the Reform of the Common Fisheries Policy. Commission Staff Working document. SEC(2010)408 final. Available online at http://ec.europa.eu/fisheries/reform/sec(2010)0428_en.pdf

Gauvin, J.R., Ward, J.M., Burgess, E.E., 1994. Description and evaluation of the wreckfish (Polyprion americanus) fishery under individual transferable quotas. Mar. Res. Econ. 9, 99-118.

Gini, C., 1921. Measurement of Inequality and Incomes. Econ. J. 31, 124-126.

González Laxe, F., 2006. Transferability of fishing rights: The Spanish case. Mar. Pol. 30(4), 379-388.

Gouvernement Français, 2009. Mémorandum français relatif à la réforme de la politique commune de la pêche. Paris. Available online at http://ec.europa.eu/fisheries/reform/docs/france_memo_fr.pdf

Grafton, R.Q., 1996. Individual transferable quotas: theory and practice. Rev. Fish Biol. Fish. 6(1), 5-20.

Grafton, R.Q., Arnason, R., Bjørndal, T., Campbell, D., Campbell, H.F., Clark, C.W., Connor, R., Dupont, D.P., Hannesson, R., Hilborn, R., Kirkley, J.E., Kompas, T., Lane, D.E., Munro, G.R., Pascoe, S., Squires, D., Steinshamn, S.I., Turris, B.R., Weninger, Q., 2006. Incentive-based approaches to sustainable fisheries. Can. J. Fish. Aquat. Sci. 63(3), 699710.

Grainger, C.A., Costello, C., 2015. Distributional Effects of the Transition to Property Rights for a Common-Pool Resource. Mar. Res. Econ. 31(1), 1-26. 
Gray, T., Korda, R., Stead, S., Jones, E., 2011. Quota discarding and distributive justice: The case of the under-10m fishing fleet in Sussex, England. Mar. Pol. 35(2), 122-129.

Gutiérrez, N.L., Hilborn, R., Defeo, O., 2011. Leadership, social capital and incentives promote successful fisheries. Nature 470(7334), 386-389.

Guyader, O., Thébaud, O., 2001. Distributional issues in the operation of rights-based fisheries management systems. Mar. Pol. 25(2), 103-112.

Guyader, O., Berthou, P., Koutsikopoulos, C., Alban, F., Demaneche, S., Gaspar, M.B., Eschbaum, R., Fahy, E., Reynal, L., Curtil, O., Frangoudes, K., Maynou, F., 2013. Small scale fisheries in Europe: A comparative analysis based on a selection of case studies. Fish. Res. 140, 1-13.

Hamon, K.G., Thébaud, O., Frusher, S., Little, L.R., 2009. A retrospective analysis of the effects of adopting individual transferable quotas in the Tasmanian red rock lobster, Jasusedwardsii, fishery. Aquat. Living Resour. 22(04), 549-558.

Holden, M., 1994. The Common Fisheries Policy: Origin, Evaluation and Future. Fishing News Books, Oxford, England.

Jentoft, S., 1989. Fisheries co-management: delegating government responsibility to fishermen's organizations. Mar. Pol. 13(2), 137-154.

Journal Officiel de la République Française (JORF), 2006. n³01 du 29 décembre 2006 page 19953 texte $n^{\circ} 104$ : Arrêté du 26 décembre 2006 établissant les modalités de répartition et de gestion collective des possibilités de pêche (quotas de captures et quotas d'effort de pêche) des navires français immatriculés dans la Communauté européenne. NOR: AGRM0602585A.

Karpoff, J.M., 1987. Suboptimal Controls in Common Resource Management: The case of the Fishery. J. Polit. Econ. 95(1), p.179-194.

Kroetz, K., Sanchirico, J. N., 2010. Economic insights into the costs of design restrictions in ITQ programs. RFF Report, Resources for the Future, 46p.

Kruskal, W.H., Wallis, W.A., 1952. Use of ranks in one-criterion variance analysis. J. Amer. Statist. Assoc. 47(260), 583-621.

Lagière, R., Macher, C., Guyader, O., 2012. Bilan et évolution des mesures de gestion mises en œuvre dans le golfe de Gascogne : Focus sur les mesures impactant directement ou indirectement la pêcherie de sole. Publications électroniques Amure, Série Rapports R-252012, $88 \mathrm{pp}$.

Larabi, Z., Guyader, O., Macher, C., Daurès, F., 2013. Quota management in a context of non-transferability of fishing rights: The French case study. Ocean Coast. Manage. 84, 1322.

Leblond, E., Daurès, F., Berthou, P., Dintheer, C., 2008. The Fisheries Information System of Ifremer: a multidisciplinary monitoring network and an integrated approach for the assessment of French fisheries, including small-scale fisheries. ICES 2008 Annual Science Conference, 22-26 september 2008, Halifax, Canada.

Le Floc'h, P., Murillas, A., Aranda, M., Daurès, F., Fitzpatrick, M., Guyader, O., Hatcher, A., Macher, C., Marchal, P., 2015. The regional management of fisheries in European Western Waters. Mar. Pol. 51, 375-384.

Le Gallic, B., Mardle, S., Boncoeur, J., 2005. Les objectifs d'une politique publique vus par les acteurs: une analyse multicritères de la politique commune de la pêche. Public Econ. 16.

Lynham, J., 2014. How have catch shares been allocated? Mar. Pol. 44, 42-48.

Macher, C., Merzéréaud, M., Le Grand, C., Frésard, M., Bertignac, M., Fifas, S., Guyader, O., Biais, G., Lissardy, M., Jadaud, A., Le Corre, G., Frangoudes, K., Daurès, F., Van Iseghem, S., Raveau, A., 2011. Groupe de travail partenarial pour la construction d'outils 
bio-économiques d'aide à la décision pour l'aménagement des pêcheries. Publications électroniques Amure, Série Rapports R-21-2011, 44.

Marchal, P., Lallemand, P., Stokes, K., Thébaud, O., 2009. A comparative review of the fisheries resource management systems in New Zealand and in the European Union. Aquat. Living Resour. 22(04), 463-481.

Matthíasson, T., 1992. Principles for Distribution of Rent from a 'Commons'. Mar. Pol. 16(3), 210-231.

Matthíasson, T., Giry, F., Agnarsson, S., 2015. Individual Transferable Quotas Allocation in Icelandic Fisheries: a Community-Oriented Inequality Analysis. Rannsóknir í félagsvísindum XVI.

Ostrom, E., 1990. Governing the commons: The evolution of institutions for collective action. Cambridge university press.

Pálsson, G., Helgason, A., 1995. Figuring Fish and Measuring Men: The Individual Transferable Quota System in the Icelandic Cod Fishery. Ocean Coast. Manage. 28(1), 117-146.

Pálsson, G., Pétursdóttir, G., 1997. Social impacts of quota systems in fisheries. Copenhagen: TemaNord, Nordic Council of Ministers. 353 p.

Pinkerton, E., Edwards, D.N., 2009. The elephant in the room: the hidden costs of leasing individual transferable fishing quotas. Mar. Pol. 33(4), 707-713.

Quillérou, E., Guyader, O., 2012. What is behind fleet evolution: a framework for flow analysis and application to the French Atlantic fleet. ICES J. Mar. Sci. 69, 1069-1077.

Raveau, A., Macher, C., Méhault, S., Merzereaud, M., Le Grand, C., Guyader, O., Bertignac, M., Fifas, S., Guillen, J., 2012. A bio-economic analysis of experimental selective devices in the Norway lobster (Nephrops norvegicus) fishery in the Bay of Biscay. Aquat. Living Resour. 25(03), 215-229.

Salvanes, K.G., Squires, D., 1996. Markets for Production Rights: Efficiency-Equity TradeOffs. Discussion paper 22/96. Norwegian School of Economics and Business Administration, Institute of Economics, Bergen, Norway.

Soliman, A., 2014. Using individual transferable quotas (ITQs) to achieve social policy objectives: A proposed intervention. Mar. Pol. 45, 76-81.

Squires, D., Kirkley, J., Tisdell, C.A., 1995. Individual transferable quotas as a fisheries management tool. Rev. Fish. Sci. 3(2), 141-169.

Sumaila, U.R., Armstrong, C.W., 2006. Distributional and efficiency effects of marine protected areas: A study of the Northeast Atlantic cod fishery. Land Econ. 82(3), 321-332.

Thébaud, O., Innes, J., Ellis, N., 2012. From anecdotes to scientific evidence? A review of recent literature on catch share systems in marine fisheries. Front. Ecol. Environ. 10(8), 433-437.

Theil, H., 1967. Economics and Information Theory. Chicago: Rand McNally and Company.

Wilen, J. E., Casey, K., 1997. Impacts of ITQs on labor: Employment and remuneration effects. In: Social Implications of Quota Systems in Fisheries, G. Pálsson and G. Petursdottir, eds., pp. 315-333. Copenhagen, Denmark: Nordic Council of Ministers. 


\section{Appendix A. Supplementary material}

\section{- Allocation criteria used by POs}

Table A1: Quota management system by PO for the sole in the Bay of Biscay and allocation criteria in 2011 (adapted from Lagière et al. 2012)

\begin{tabular}{|c|c|c|c|}
\hline PO & Sub-group & Quota management & $\begin{array}{l}\text { Allocation method and } \\
\text { criteria }\end{array}$ \\
\hline \multirow{2}{*}{ PMA } & $\begin{array}{l}\text { Vessels with production }>2 \\
\text { tons }\end{array}$ & Individual limits & $\begin{array}{l}\text { Mean production by vessel } \\
2004-2006\end{array}$ \\
\hline & $\begin{array}{l}\text { Vessels with production }<2 \\
\text { tons }\end{array}$ & Individual limits & Package of 2 tons per vessel \\
\hline \multirow{4}{*}{ ОРОВ } & Large gillnetters $>18 \mathrm{~m}$ & Individual limits & Package of 26 tons per vessel \\
\hline & Large gillnetters $<18 \mathrm{~m}$ & Individual limits & Package of 18 tons per vessel \\
\hline & Inshore trawlers & Collective quota & \\
\hline & Small-scale fishery & Collective quota & \\
\hline OPPAN & All vessels & Collective quota & \\
\hline OP YEU & All vessels & Collective quota & \\
\hline \multirow{4}{*}{ OP VENDEE } & Trawlers Sables d'Olonne & Collective quota & \\
\hline & Gillnetters Sables d'Olonne & Collective quota & \\
\hline & $\begin{array}{l}\text { Trawlers Saint Gilles Croix } \\
\text { de Vie }\end{array}$ & Collective quota & \\
\hline & $\begin{array}{l}\text { Gillnetters Saint Gilles Croix } \\
\text { de Vie }\end{array}$ & Collective quota & \\
\hline \multirow{4}{*}{$\begin{array}{l}\text { FROM SUD } \\
\text { OUEST }\end{array}$} & Gillnetters Royan & Individual limits & $\begin{array}{l}\text { Historical landings records } \\
(2001-2003)\end{array}$ \\
\hline & $\begin{array}{l}\text { Binational French-Spanish } \\
\text { fleet }\end{array}$ & Collective quota & \\
\hline & Seafaring fleet & Collective quota & \\
\hline & Coureauleur fleet & Collective quota & \\
\hline LA COTINIERE & All vessels & Individual limits & $\begin{array}{l}\text { Historical landings records } \\
(2001-2003)+\text { Production by } \\
\text { vessel } 2008-2010\end{array}$ \\
\hline \multirow{2}{*}{ ARCA-COOP } & $\begin{array}{l}\text { Offshore (extra-bassin) } \\
\text { vessels }\end{array}$ & Individual limits & $\begin{array}{l}\text { Maximum production of the } \\
\text { last } 10 \text { years }\end{array}$ \\
\hline & $\begin{array}{l}\text { Inshore (intra-bassin) } \\
\text { vessels }\end{array}$ & Collective quota & \\
\hline \multirow[t]{2}{*}{ CAPSUD-OP } & Sole-targeting vessels & Individual limits & $\begin{array}{l}\text { Historical landings records } \\
(2001-2003)\end{array}$ \\
\hline & Others & Collective quota & \\
\hline
\end{tabular}


- Fleet composition and characteristics by length class and maritime regions

Table A2. Number of vessels and average vessel characteristics by length class of the Bay of Biscay sole fishery in 2011 (vessels with landings $>1$ metric ton)

\begin{tabular}{|c|c|c|c|c|c|c|c|c|}
\hline Length Class & $\begin{array}{c}\text { Number } \\
\text { of vessels }\end{array}$ & $\begin{array}{l}\text { Vessel } \\
\text { length } \\
\text { (m) }\end{array}$ & Crewsize & $\begin{array}{c}\text { Days } \\
\text { at sea }\end{array}$ & $\begin{array}{c}\text { Gross } \\
\text { revenue } \\
\text { (k€) }\end{array}$ & $\begin{array}{c}\text { Sole Gross } \\
\text { revenue } \\
(\mathrm{k} €)\end{array}$ & $\begin{array}{c}\text { Sole } \\
\text { Landings } \\
\text { (Tons) }\end{array}$ & $\begin{array}{c}\text { Sole } \\
\text { dependency } \\
\text { (\% Gross } \\
\text { revenue) } \\
\end{array}$ \\
\hline$>=20 \mathrm{~m}$ & 34 & 21.4 & 5.2 & 250 & 944 & 276 & 23.8 & 29.3 \\
\hline$[16-20[\mathrm{~m}$ & 69 & 17.5 & 4.5 & 234 & 736 & 170 & 14.8 & 23.1 \\
\hline$[12-16[\mathrm{~m}$ & 120 & 14.2 & 3.4 & 211 & 502 & 123 & 10.7 & 24.4 \\
\hline$[10-12[\mathrm{~m}$ & 163 & 11.5 & 2.5 & 180 & 265 & 76 & 6.3 & 28.7 \\
\hline$<10 \mathrm{~m}$ & 86 & 9.1 & 1.6 & 143 & 129 & 44 & 3.4 & 34.2 \\
\hline Average & - & 13.3 & 3.1 & 194 & 419 & 110 & 9.4 & 25.7 \\
\hline
\end{tabular}

Table A3. Number of vessels and average vessel characteristics by maritime district (ordered North to South) of the Bay of Biscay sole fishery in 2011 (vessels with landings > 1 metric ton)

\begin{tabular}{|c|c|c|c|c|c|c|c|c|}
\hline $\begin{array}{l}\text { Maritime } \\
\text { district }\end{array}$ & $\begin{array}{c}\text { Number } \\
\text { of vessels }\end{array}$ & $\begin{array}{l}\text { Vessel } \\
\text { length } \\
\text { (m) }\end{array}$ & Crewsize & $\begin{array}{c}\text { Days at } \\
\text { sea }\end{array}$ & $\begin{array}{c}\text { Gross } \\
\text { revenue } \\
\text { (k€) }\end{array}$ & $\begin{array}{c}\text { Sole } \\
\text { Gross } \\
\text { revenue } \\
\text { (k€) }\end{array}$ & $\begin{array}{c}\text { Sole } \\
\text { Landings } \\
\text { (Tons) }\end{array}$ & $\begin{array}{c}\text { Sole } \\
\text { dependency } \\
\text { (\% Gross } \\
\text { revenue) } \\
\end{array}$ \\
\hline Morlaix & 6 & 17.0 & 4.2 & 210 & 739 & 214 & 19.0 & 29.0 \\
\hline Guilvinec & 71 & 13.9 & 2.6 & 204 & 383 & 38 & 2.9 & 9.9 \\
\hline Concarneau & 17 & 13.0 & 3.0 & 203 & 347 & 19 & 1.6 & 5.6 \\
\hline Lorient & 50 & 14.3 & 3.8 & 216 & 533 & 98 & 8.1 & 18.3 \\
\hline Auray & 18 & 10.9 & 2.7 & 158 & 201 & 46 & 3.7 & 23.1 \\
\hline Vannes & 6 & 9.6 & 1.5 & 133 & 117 & 36 & 2.4 & 30.7 \\
\hline $\begin{array}{l}\text { Saint- } \\
\text { Nazaire } \\
\end{array}$ & 49 & 13.8 & 3.3 & 206 & 540 & 58 & 4.6 & 10.8 \\
\hline Noirmoutier & 27 & 12.6 & 3.1 & 176 & 413 & 235 & 19.5 & 57.0 \\
\hline L'Ile-d'Yeu & 22 & 14.3 & 3.7 & 195 & 435 & 190 & 16.6 & 43.7 \\
\hline $\begin{array}{l}\text { Les Sables- } \\
\text { d'Olonne }\end{array}$ & 50 & 12.2 & 2.6 & 177 & 332 & 141 & 12.1 & 42.4 \\
\hline La Rochelle & 24 & 13.8 & 2.7 & 182 & 328 & 81 & 6.9 & 24.8 \\
\hline Ile d'Oléron & 25 & 12.5 & 2.6 & 203 & 402 & 91 & 7.9 & 22.6 \\
\hline Marennes & 48 & 13.0 & 2.8 & 186 & 427 & 136 & 11.9 & 32.0 \\
\hline Arcachon & 27 & 14.8 & 4.0 & 217 & 587 & 296 & 26.0 & 50.4 \\
\hline Bayonne & 25 & 13.0 & 3.4 & 180 & 362 & 96 & 8.3 & 26.5 \\
\hline Others & 7 & 12.0 & 2.6 & 168 & 279 & 34 & 2.8 & 12.2 \\
\hline Average & - & 13.3 & 3.1 & 194 & 419 & 110 & 9.4 & 25.7 \\
\hline
\end{tabular}


Table A4. Number of vessels and average vessel characteristics by Producer Organization in the Bay of Biscay sole fishery in 2011 (vessels with landings > 1 metric ton)

\begin{tabular}{lcclcc}
\hline $\begin{array}{c}\text { Producer } \\
\text { Organization }\end{array}$ & $\begin{array}{c}\text { Number } \\
\text { of vessels }\end{array}$ & $\begin{array}{c}\text { Share of the total } \\
\text { number of } \\
\text { vessels of the PO } \\
\text { (\%) }\end{array}$ & $\begin{array}{c}\text { Main fleet } \\
\text { segments }\end{array}$ & $\begin{array}{c}\text { Sole } \\
\text { Landings } \\
\text { (Tons) }\end{array}$ & $\begin{array}{c}\text { Sole } \\
\text { dependency } \\
\text { (\% Gross } \\
\text { revenue) }\end{array}$ \\
\hline PMA & 163 & 33.9 & $\begin{array}{l}\text { Mixed bottom } \\
\text { trawlers } \\
\text { Nephrops } \\
\text { trawlers }\end{array}$ & 4.8 & 13.0 \\
\hline OPOB & 50 & 14.9 & $\begin{array}{l}\text { Nephrops } \\
\text { trawlers } \\
\text { Sole gillnetters }\end{array}$ & 5.3 & 15.2 \\
\hline OPPAN & 27 & 27.0 & Sole gillnetters & 21.8 & 59.2 \\
\hline OP ILE D YEU & 18 & 54.5 & Sole gillnetters & 19.3 & 48.7 \\
\hline OP VENDEE & 44 & 40.2 & $\begin{array}{l}\text { Mixed bottom } \\
\text { trawlers } \\
\text { Sole gillnetters }\end{array}$ & 12.4 & 42.6 \\
\hline FROM SUD-OUEST & 28 & 26.7 & $\begin{array}{l}\text { Sole gillnetters } \\
\text { Mixed bottom } \\
\text { trawlers }\end{array}$ & 14.8 & 39.5 \\
\hline OP LA COTINIERE & 67 & 65.0 & $\begin{array}{l}\text { Mixed bottom } \\
\text { trawlers }\end{array}$ & 7.6 & 21.9 \\
\hline ARCA-COOP & 24 & 68.5 & Sole gillnetters & 24.3 & 49.0 \\
\hline CAPSUD-OP & 22 & 31.3 & Sole gillnetters & 10.9 & 33.6 \\
\hline Non PO & 29 & & Sole gillnetters & 5.2 & 26.8 \\
\hline
\end{tabular}

- Distribution of landings and historical landings in the total population

Table A5. Composition of the population of all Bay of Biscay vessels with non-zero sole landings in 2011 or non-zero historical landings records, and relative contributions of sub-populations to landings and historical landings records (SHL = strict historical landings)

\begin{tabular}{|c|c|c|c|c|c|}
\hline & $\begin{array}{c}\text { Number } \\
\text { of vessels }\end{array}$ & $\begin{array}{l}\text { Landings } \\
2011 \\
\text { (Tons) }\end{array}$ & $\begin{array}{c}\% \\
\text { Landings } \\
2011\end{array}$ & $\begin{array}{l}\text { SHL vessel } \\
\text { limits } \\
\text { (Tons) }\end{array}$ & $\begin{array}{l}\text { \% Historical } \\
\text { landings } \\
\text { records }\end{array}$ \\
\hline Total population & 1535 & 4259 & 100 & 3906 & 89 \\
\hline $\begin{array}{l}\text { Inactive vessels with } \\
\text { Historical landings records } \\
>0\end{array}$ & 255 & 0 & 0 & 493 & 11 \\
\hline $\begin{array}{l}\text { Vessels with Historical } \\
\text { landings records }>0 \& \\
2011 \text { landings }=0\end{array}$ & 241 & 0 & 0 & 345 & 8 \\
\hline $\begin{array}{l}\text { Vessels with } 2011 \text { landings } \\
\text { in ]0,1000kg[ }\end{array}$ & 567 & 132 & 3 & 270 & 6 \\
\hline $\begin{array}{l}\text { Vessels with } 2011 \\
\text { landings }>1000 \mathrm{~kg}\end{array}$ & 472 & 4127 & 97 & 2798 & 64 \\
\hline
\end{tabular}

${ }^{A}$ based on the final French sole quota of 4380 Tons for ICES areas VIIIa-b in 2011.

${ }^{B}$ about $11 \%$ of the historical landings records were placed in the national and PO reserves, so that the total population accounted for $89 \%$ of historical landings records. 